Nana Usnawanti: Pengaruh Pelatihan Safe Injection Terhadap Peningkatan Pengetahuan, Sikap, dan Keterampilan Bidan Desa dalam Pelaksanaan Imunisasi di Kabupaten magetan 
Nana Usnawanti: Pengaruh Pelatihan Safe Injection Terhadap Peningkatan Pengetahuan, Sikap, dan Keterampilan Bidan Desa dalam Pelaksanaan Imunisasi di Kabupaten magetan 


\title{
Pengaruh Pelatihan Safe Injection Terhadap Peningkatan Pengetahuan, Sikap, dan Keterampilan Bidan Desa Dalam Pelaksanaan Imunisasi Di Kabupaten Magetan
}

\author{
Nana Usnawati ${ }^{1}$, Dwi Prasetyo ${ }^{2}$, Elsa Pudji Setiawati ${ }^{3}$, Farid Husin $^{4}$, Kusnandi Rusmil $^{5}$, Meita Dhamayanti ${ }^{6}$ \\ ${ }^{1}$ Mahasiswa Prodi Magister Kebidanan Fakultas Kedokteran Universitas Padjadjaran \\ ${ }^{2,5,6}$ Departemen Ilmu Kesehatan Anak Fakultas Kedokteran Universitas Padjadjaran \\ ${ }^{3}$ Departemen Ilmu Kesehatan Masyarakat Fakultas Kedokteran Universitas Padjadjaran \\ ${ }^{4}$ Departemen Obstetri dan Ginekologi Fakultas Kedokteran Universitas Padjadjaran
}

\begin{abstract}
Abstrak
Anak merupakan potensi utama bagi masa depan bangsa. Konvensi hak anak menyatakan bahwa anak berhak memperoleh kesehatan dan kesejahteraan dasar, salah satunya adalah imunisasi. Cakupan imunisasi di kabupaten Magetan sudah baik, tetapi seiring dengan meningkatnya cakupan, terjadi peningkatan kejadian ikutan pasca imunisasi (KIPI). Bidan mempunyai peran penting dan strategis dalam pelaksanaan imunisasi. Pengetahuan, sikap, dan keterampilan safe injection bidan dalam pelaksanaan imunisasi masih perlu ditingkatkan. Salah satu upaya untuk meningkatkan pengetahuan, sikap, dan keterampilan adalah memberikan pelatihan. Tujuan penelitian ini menganalisis pengaruh pelatihan safe injection terhadap peningkatan pengetahuan, sikap, dan keterampilan bidan desa dalam pelaksanaan imunisasi.Penelitian ini menggunakan rancangan quasy experiments pre post test with control design yang dilakukan pada 60 bidan (kelompok perlakuan 30 bidan dan kelompok kontrol 30 bidan), yang diambil secara proporsional. Pelatihan safe injection pelaksanaan imunisasi dilakukan pada kelompok perlakuan. Pengetahuan dan sikap diukur mengunakan kuesioner. Keterampilan diukur menggunakan daftar tilik. Analisis data menggunakan uji t, uji Mann Whitney, uji Wilcoxon dan Chi Square. Hasil penelitian menunjukkan bahwa terdapat pengaruh pelatihan safe injection terhadap peningkatan pengetahuan, sikap, dan keterampilan bidan desa dalam pelaksanaan imunisasi $(\mathrm{p}<0,05)$. Peningkatan pengetahuan, sikap, dan keterampilan pada kelompok perlakuan lebih tinggi dibanding kelompok kontrol. Pada kelompok perlakuan terjadi peningkatan pengetahuan $(22,23 \%)$, sikap (10,7\%), dan keterampilan imunisasi BCG, DPT-HB, campak (50,73\%; 46,10\%; 53,87\%). Pada kelompok kontrol terjadi peningkatan pengetahuan $(0,6 \%)$, sikap $(1,87 \%)$, dan keterampilan imunisasi BCG, DPT-HB, campak $(9,67 \% ; 9,60 \% ; 12,37 \%)$.
\end{abstract}

Kata kunci: Bidan Desa, Imunisasi, Kompetensi, Pelatihan, Safe Injection 


\title{
The Impact of Safe Injection Training Towards the Improvement of Midwive Knowledge, Attitude, and Practice in the Immunization Implementation in Magetan Regency
}

\begin{abstract}
Children are primary potential for the nation in the future. Child rights convention states that children are entitled to health and basic welfare, such as immunization. Immunization coverage in Magetan regency has been already well, however adverse events following immunization (AEFI) will be increased along with the increasing of the coverage. Midwives have an important and strategic role in the implementation of immunization. Their knowledge, attitude, and practice in implementing safe injection immunization needs to be improved. One of the efforts is conducting training. The purpose of this study is to analyze the influence of safe injection training toward the improvement of knowledge, attitude, and practice owned by midwives in the implementation of immunization. This research used the design of quasy experiments pre post test with control design with involved to 60 midwives ( 30 midwives in the treatment group and 30 midwives in the control group) who were determined with proportionally technique. Training of safe injection immunization was given to the treatment group. Knowledge and attitude were measured using questionnaire. Practice was measured using checklist. Then data were analyzed using $t$ test, Mann Whitney test, Wilcoxon test and Chi Square. The result of this research showed that there was an influence of training toward the improvement of safe injection knowledge, attitude, and practice owned by midwives in the implementation of immunization $(\mathrm{p}<0,05)$. The increase knowledge, attitude, and practice in treatment group is higher than in control group. In the treatment group there was an increase of knowledge $(22.23 \%)$, attitude $(10.7 \%)$, and practice BCG, DPT-HB, measles $(50.73 \%, 46.10 \%$, $53.87 \%)$. In the control group there was an increase of knowledge $(0.6 \%)$, attitude $(1.87 \%)$, and practice BCG, DPT-HB, measles $(9.67 \%, 9.60 \%, 12.37 \%)$. The conclusion of this research reveals that there is an influence of the safe injection training towards increase knowledge, attitude, and practice midwives in the implementation of immunization. Improving knowledge, attitude, and practice through training needs to be done and followed by evaluation and supportive supervision.
\end{abstract}

Keywords: Midwife, Immunization, Competence, Training, Safe Injection 


\section{Pendahuluan}

Anak adalah potensi utama bagi masa depan bangsa. Konvensi hak anak menyatakan salah satu hak anak adalah memperoleh kesehatan dan kesejahteraan dasar. ${ }^{1}$ Salah satu kebutuhan dasar asuh bagi anak adalah perawatan kesehatan dini berupa imunisasi. ${ }^{2}$ Imunisasi adalah suatu upaya untuk menimbulkan/meningkatkan kekebalan seseorang secara aktif terhadap suatu penyakit, sehingga bila suatu saat terpajan dengan penyakit tersebut tidak akan sakit atau hanya mengalami sakit ringan. Imunisasi merupakan salah satu upaya untuk mencegah terjadinya penyakit menular yang merupakan salah satu kegiatan prioritas Kementerian Kesehatan sebagai salah satu bentuk nyata untuk mencapai Millenium Development Goals (MDGs) khususnya menurunkan angka kematian pada anak. ${ }^{1}$

Data profil kesehatan Kabupaten Magetan tahun 2012 menunjukkan bahwa cakupan imunisasi pada bayi sudah baik ${ }^{3}$. Seiring dengan cakupan imunisasi yang tinggi, maka terjadi peningkatan kejadian ikutan pasca imunisasi (KIPI) di masyarakat. ${ }^{1}$ Proses pemberian imunisasi harus memperhatikan keamanan vaksin dan keamanan penyuntikan agar tidak terjadi penularan penyakit terhadap tenaga pelaksana imunisasi dan masyarakat serta menghindari terjadinya KIPI. KIPI adalah kejadian medik yang berhubungan dengan imunisasi. Penyebab KIPI berdasarkan klasifikasi lapangan terdiri dari lima kelompok penyebab, yaitu kesalahan prosedur/tehnik pelaksanaan (programmatic errors), reaksi suntikan, induksi/reaksi vaksin, faktor kebetulan/koinsiden, dan penyebab yang tidak diketahui. ${ }^{1,4}$

Di Kabupaten Magetan terjadi peningkatan kasus KIPI pada bayi dari 6 kasus tahun 2012 menjadi 13 kasus tahun 2013. Berdasarkan laporan Dinas Kesehatan Kabupaten Magetan diperoleh informasi bahwa dari 44 bidan, pengetahuan tentang safe injection dalam pelaksanaan imunisasi $60 \%$ termasuk kategori kurang, dan penyebab terjadinya kasus KIPI karena kesalahan tehnik/prosedur imunisasi dalam menentukan lokasi dan cara penyuntikan yang dilakukan oleh bidan desa. ${ }^{4}$

Dunia dan pemerintah selalu berupaya melaksanakan peningkatan mutu pelayanan imunisasi dengan menetapkan standar pemberian suntikan yang aman (safe injection practices) bagi penerima suntikan yang dikaitkan dengan pengelolaan limbah medis tajam yang aman (waste disposal management), bagi petugas maupun lingkungan. ${ }^{1}$ World Health Organization (WHO) memperkirakan 16 miliar pemberian suntikan terjadi setiap tahun di negara berkembang dan setidaknya $50-70 \%$ suntikan diperkirakan tidak aman. Pemberian suntikan yang tidak aman berrisiko terhadap kesehatan yang serius pada penerima suntikan, petugas kesehatan, dan masyarakat umum. Penggunaan jarum suntik sekali pakai dapat menurunkan risiko dari suntikan yang tidak aman. Pembuangan limbah dan pengelolaan vaksin yang tidak tepat merupakan masalah penting yang terkait dengan keamanan suntikan. ${ }^{5}$ Berkaitan dengan hal tersebut, penelitian di Nigeria menunjukkan hasil bahwa $80,4 \%$ petugas imunisasi memiliki pengetahuan yang kurang mengenai penyuntikan yang aman dan tidak mengetahui adanya kebijakan tentang keamanan suntikan. ${ }^{6}$

Kewenangan bidan sesuai Peraturan Menteri Kesehatan RI Nomor 1464/Menkes/Per/X/2010 dalam pelayanan kesehatan anak salah satunya adalah pemberian imunisasi rutin sesuai program Pemerintah. $^{7}$ Dalam kurikulum pendidikan kebidanan, calon bidan sudah memperoleh materi tentang imunisasi. Dalam menjalankan tugas sesuai kewenangannya, bidan dituntut memiliki kompetensi yang baik. Kompetensi mencakup kemampuan dalam aspek pengetahuan, sikap, dan keterampilan yang dilaksanakan sesuai dengan standar yang telah ditentukan. ${ }^{8}$ Kompetensi bidan sesuai Keputusan Menteri Kesehatan RI Nomor 369/Menkes/SK/VII/2007 dalam asuhan pada bayi dan balita adalah memberikan asuhan bermutu tinggi komprehensif pada bayi dan balita sehat (1 bulan-5 tahun), termasuk melaksanakan pemberian imunisasi pada bayi dan anak. ${ }^{9}$ Permenkes RI Nomor 42 tahun 2013 tentang penyelenggaraan imunisasi pasal 27 menyatakan bahwa pelayanan imunisasi dilaksanakan oleh dokter dan dokter spesialis; selain dokter dan dokter spesialis, bidan dapat melaksanakan pelayanan imunisasi wajib sesuai dengan ketentuan peraturan perundangundangan; dokter di puskesmas dapat mendelegasikan kewenangan pelayanan imunisasi kepada bidan dan perawat sesuai ketentuan peraturan perundang-undangan untuk melaksanakan imunisasi wajib sesuai program Pemerintah. ${ }^{1}$ 
Bidan mempunyai peran penting dan strategis dalam pelaksanaan program imunisasi. Kompetensi bidan desa dalam pelaksanaan pemberian imunisasi pada bayi dan balita di Kabupaten Magetan masih perlu ditingkatkan. Salah satu upaya yang dapat dilakukan adalah dengan memberikan pelatihan safe injection. Pelatihan bertujuan untuk meningkatkan kompetensi yang meliputi pengetahuan, sikap, dan keterampilan dalam rangka meningkatkan kinerja dan kualitas petugas. ${ }^{8}$

Tujuan penelitian ini adalah menganalisis pengaruh pelatihan safe injection terhadap peningkatan pengetahuan, sikap, dan keterampilan bidan desa dalam pelaksanaan imunisasi di kabupaten Magetan.

\section{Metode}

Penelitian ini menggunakan rancangan quasy experiments pre post test with control design yang dilakukan pada 60 bidan desa (kelompok perlakuan 30 orang dan kelompok kontrol 30 orang), yang diambil secara proporsional. Kriteria inklusi yaitu bidan yang bekerja di desa, pendidikan minimal D-III Kebidanan dan lama bekerja minimal 1 tahun. Penelitian dilaksanakan pada bulan April sampai dengan bulan Mei 2014. Pelatihan safe injection pelaksanaan imunisasi dilakukan pada kelompok perlakuan. Pengetahuan dan sikap diukur mengunakan kuesioner. Keterampilan diukur menggunakan daftar tilik. Analisis data menggunakan uji t, uji Mann Whitney, uji Wilcoxon dan Chi Square.

\section{Hasil}

Dalam penelitian ini didapatkan 60 bidan desa yang memenuhi kriteria penelitian dan seluruhnya mengikuti rangkaian penelitian. Pengetahuan, sikap, dan keterampilan safe injection bidan desa antara pretes dengan postes pada kelompok perlakuan menunjukkan perbedaan bermakna $(p<0,05)$. Pada kelompok kontrol diperoleh hasil bahwa variabel pengetahuan dan sikap antara pretes dengan postes tidak menunjukkan perbedaan bermakna $(\mathrm{p}>0,05)$, sedangkan variabel keterampilan menunjukkan perbedaan bermakna $(p<0,05)$. Peningkatan pengetahuan, sikap, dan keterampilan safe injection bidan desa dalam pelaksanaan imunisasi pada kelompok perlakuan dan kelompok kontrol, menunjukkan perbedaan bermakna $(\mathrm{p}<0,05)$.

\section{Pembahasan}

Karakteristik responden pada kelompok perlakuan dan kelompok kontrol tidak menunjukkan perbedaan (setara) sehingga layak untuk dibandingkan. Kompetensi adalah kemampuan individu yang mencakup pengetahuan, sikap, dan keterampilan yang sesuai standar yang ditetapkan. Kompetensi safe injection dalam pelaksanaan imunisasi memiliki pengertian yang luas, tidak hanya prosedur tunggal dalam pemberian suntikan, melainkan memerlukan pengetahuan dan keterampilan sebelum, selama, dan sesudah pelayanan imunisasi. Penelitian ini mengukur peningkatan pengetahuan, sikap dan keterampilan yang merupakan komponen dari kompetensi. Dengan adanya peningkatan pada pengetahuan, sikap dan keterampilan, terjadi peningkatan pada kompetensi. Tiga hal yang penting berkaitan dengan kompetensi pelaksanaan imunisasi adalah petugas (bidan) pelaksana yang kompeten, pelaksanaan imunisasi yang benar sesuai prosedur, dan hasil pelayanan imunisasi yang baik. ${ }^{10}$ Kewenangan bidan sesuai Peraturan Menteri Kesehatan RI Nomor 1464/ Menkes/Per /X/2010 dalam pelayanan kesehatan anak salah satunya adalah pemberian imunisasi rutin sesuai program Pemerintah. ${ }^{7}$ Permenkes RI Nomor 42 tahun 2013 tentang penyelenggaraan imunisasi pasal 27 menyatakan bahwa pelayanan imunisasi dilaksanakan oleh dokter dan dokter spesialis; selain dokter dan dokter spesialis, bidan dapat melaksanakan pelayanan imunisasi wajib sesuai dengan ketentuan peraturan perundangundangan; dokter di puskesmas dapat mendelegasikan kewenangan pelayanan imunisasi kepada bidan dan perawat sesuai ketentuan peraturan perundang-undangan untuk melaksanakan imunisasi wajib sesuai program Pemerintah. ${ }^{1}$ Bidan mempunyai peran penting dan strategis dalam pelaksanaan program imunisasi. Petugas (bidan) yang kompeten harus memiliki pengetahuan dan sikap yang baik, serta terampil. Dalam pelaksanaan imunisasi, petugas (bidan) harus sesuai dengan prosedur, dengan harapan dapat mengurangi kejadian KIPI. Berikut ini dibahas tentang peningkatan pengetahuan, sikap, dan keterampilan sebagai komponen dari kompetensi. 
Nana Usnawanti: Pengaruh Pelatihan Safe Injection Terhadap Peningkatan Pengetahuan, Sikap, dan Keterampilan Bidan Desa dalam Pelaksanaan Imunisasi di Kabupaten magetan

Tabel 1 Pengetahuan, Sikap, dan Keterampilan Safe Injection Bidan Desa dalam Pelaksanaan Imunisasi Sebelum dan Setelah Pelatihan

\begin{tabular}{|c|c|c|c|c|c|c|}
\hline & \multirow{3}{*}{ Variabel } & \multicolumn{4}{|c|}{ Kelompok } & \multirow{3}{*}{ Nilai p } \\
\hline & & \multicolumn{2}{|c|}{ Perlakuan } & \multicolumn{2}{|c|}{ Kontrol } & \\
\hline & & Pretes & Postes & Pretes & Postes & \\
\hline \multirow[t]{6}{*}{1.} & Pengetahuan & & & & & \\
\hline & Mean (SD) & $66,63(6,7)$ & $80,93(6,6)$ & $69,83(7,8)$ & $70,33(8,7)$ & \\
\hline & Median & 67 & 81 & 69 & 72 & \\
\hline & Rentang & $47-78$ & $69-94$ & $50-83$ & $47-81$ & \\
\hline & Nilai p & \multicolumn{2}{|c|}{$<0,001 *$} & \multicolumn{2}{|c|}{$0,702 * *$} & \\
\hline & Peningkatan (\%) & \multicolumn{2}{|c|}{22,23} & \multicolumn{2}{|c|}{0,6} & $<0,001 * * *$ \\
\hline \multirow[t]{6}{*}{2.} & Sikap & & & & & \\
\hline & Mean (SD) & $79,17(7,9)$ & $87,07(6,3)$ & $79,03(5,8)$ & $80,47(7,0)$ & \\
\hline & Median & 78 & 87 & 80 & 79 & \\
\hline & Rentang & $57-99$ & $75-100$ & $67-89$ & $67-94$ & \\
\hline & Nilai p & \multicolumn{2}{|c|}{$<0,001 *$} & \multicolumn{2}{|c|}{$1,04 *$} & \\
\hline & Peningkatan (\%) & \multicolumn{2}{|c|}{10,70} & \multicolumn{2}{|c|}{1,87} & $<0,001 * * *$ \\
\hline \multirow[t]{6}{*}{3.} & Keterampilan BCG & & & & & \\
\hline & Mean (SD) & $66,93(8,6)$ & $99,17(1,9)$ & $67,5(14,6)$ & $73,17(16,0)$ & \\
\hline & Median & 67 & 100 & 67,5 & 79 & \\
\hline & Rentang & $50-83$ & 93-100 & $38-90$ & $50-95$ & \\
\hline & Nilai p & \multicolumn{2}{|c|}{$<0,001 * *$} & \multicolumn{2}{|c|}{$\mathbf{0 , 0 0 5 * *}$} & \\
\hline & Peningkatan (\%) & \multicolumn{2}{|c|}{$\mathbf{5 0 , 7 3}$} & \multicolumn{2}{|c|}{9,67} & $<0,001 * * *$ \\
\hline \multirow[t]{6}{*}{4.} & $\begin{array}{l}\text { Keterampilan } \\
\text { DPT-HB }\end{array}$ & & & & & \\
\hline & Mean (SD) & $68,6(8,3)$ & $98,9(1,9)$ & $69,1(13,2)$ & $75,43(15,6)$ & \\
\hline & Median & 69 & 100 & 71,5 & 80 & \\
\hline & Rentang & $52-86$ & $95-100$ & $48-88$ & $50-98$ & \\
\hline & Nilai p & \multicolumn{2}{|c|}{$<0,001 * *$} & \multicolumn{2}{|c|}{$0,001 * *$} & \\
\hline & Peningkatan (\%) & \multicolumn{2}{|c|}{46,10} & \multicolumn{2}{|c|}{9,60} & $<0,001 * * *$ \\
\hline \multirow[t]{6}{*}{5.} & $\begin{array}{l}\text { Keterampilan } \\
\text { Campak }\end{array}$ & & & & & \\
\hline & Mean (SD) & $65,4(9,3)$ & $99,0(1,4)$ & $67,53(13,7)$ & $75,07(13,8)$ & \\
\hline & Median & 66 & 100 & 66 & 80 & \\
\hline & Rentang & $47-84$ & $95-100$ & $47-91$ & $51-98$ & \\
\hline & Nilai p & \multicolumn{2}{|c|}{$<0,001 * *$} & \multicolumn{2}{|c|}{$<0,001 * *$} & \\
\hline & Peningkatan (\%) & \multicolumn{2}{|c|}{$\mathbf{5 3 , 8 7}$} & & & $<0,001 * * *$ \\
\hline
\end{tabular}

Keterangan :

*analisis dilakukan dengan menggunakan uji t berpasangan

**: analisis dilakukan dengan menggunakan uji Wilcoxon

***: analisis dilakukan dengan menggunakan uji Mann Whitney

$\%$ peningkatan $=($ data postes-pretes $) /$ data pretes $\mathrm{x} 100$ 
Berdasar tabel 1, terdapat perbedaan bermakna pengetahuan safe injection bidan desa dalam pelaksanaan imunisasi sebelum dan setelah pelatihan pada kelompok perlakuan dengan nilai $\mathrm{p}<0,05$. Rata-rata skor pengetahuan sebelum pelatihan adalah 66,63 (kategori kurang) menjadi 80,93 (kategori baik) setelah pelatihan dengan peningkatan sebesar $22,23 \%$.

Pengetahuan setelah pelatihan pada kelompok perlakuan memiliki rentang 69-94, hal ini menunjukkan bahwa setelah pelatihan masih ada responden yang memiliki pengetahuan kurang baik. Hal ini dimungkinkan karena masing-masing responden memiliki motivasi belajar yang tidak sama. Motivasi merupakan salah satu aspek dinamis yang sangat penting dalam proses pembelajaran. ${ }^{11,12}$ Seseorang yang memiliki motivasi belajar tinggi cenderung akan memperoleh hasil belajar yang tinggi. Sering terjadi seseorang yang kurang berprestasi bukan disebabkan oleh kemampuan yang kurang, melainkan karena tidak adanya motivasi untuk belajar sehingga ia tidak berusaha mengerahkan segala kemampuannya. ${ }^{12}$

Hasil yang berbeda terlihat pada kelompok kontrol, yaitu tidak terdapat perbedaan $(\mathrm{p}>0,05)$ pengetahuan antara pretes dan postes. Rata-rata skor pengetahuan cenderung menetap $(69,83$ menjadi 70,33) dan termasuk dalam kategori kurang, dengan peningkatan pengetahuan hanya $0,6 \%$. Hal ini disebabkan karena pada kelompok kontrol tidak mendapatkan materi pelatihan, sehingga mereka hanya mengandalkan ingatan tentang materi imunisasi ketika mereka kuliah.

Persentase peningkatan pengetahuan antara kelompok perlakuan dan kelompok kontrol menunjukkan perbedaan bermakna $(p<0,05)$, sehingga dapat disimpulkan bahwa pelatihan berpengaruh terhadap peningkatan pengetahuan safe injection bidan desa dalam pelaksanaan imunisasi.

Hasil penelitian ini selaras dengan penelitian Dewi ${ }^{13}$ yang menunjukkan bahwa pelatihan mempunyai pengaruh terhadap peningkatan pengetahuan pengelolaan program imunisasi. Hasil yang sama diperoleh dari penelitian Muflihah $^{14}$ yang memberikan informasi bahwa peningkatan pengetahuan setelah pelatihan pada kelompok intervensi lebih tinggi daripada kelompok kontrol

Pengetahuan adalah hasil dari tahu dan terjadi setelah orang melakukan penginderaan terhadap objek tertentu. Penginderaan terjadi melalui panca indera manusia yaitu indera penglihatan, pendengaran, penciuman, rasa, dan raba. Sebagian besar pengetahuan manusia diperoleh melalui mata dan telinga. ${ }^{15}$

Pelatihan safe injection merupakan pelatihan keahlian (skills training) yang terbukti meningkatkan pengetahuan. Pelatihan ini menggunakan pendekatan mastery learning (belajar sampai mahir), menggunakan prinsip belajar orang dewasa, belajar berdasarkan kompetensi, dan mengunakan teknik pelatihan humanistik. ${ }^{16}$ Materi pelatihan disampaikan dengan menggunakan metode belajar yang melibatkan peserta secara aktif dalam belajar. Makin aktif keterlibatan peserta pelatihan dalam proses pelatihan, akan semakin tinggi motivasinya dan semakin besar retensinya. Penelitian Wibawati ${ }^{11}$ menunjukkan bahwa motivasi merupakan salah satu aspek dinamis yang penting dalam proses pembelajaran. Romiszowki dalam Suciati ${ }^{12}$ menyatakan bahwa kinerja atau performance yang rendah dapat disebabkan oleh beberapa faktor yang berasal dari dalam dan luar. Seseorang yang penampilan kerjanya rendah salah satunya disebabkan karena tidak menguasai pengetahuan dan keterampilan. Pengetahuan dapat diperoleh dari pendidikan dan pelatihan yang diikuti. Keikutsertaan dan lamanya pelatihan akan diarahkan pada peningkatan kemampuan dan keahlian serta pengetahuan peserta.

Berdasarkan tabel 1, terdapat perbedaan yang bermakna sikap safe injection bidan desa dalam pelaksanaan imunisasi sebelum dengan setelah pelatihan pada kelompok perlakuan dengan nilai $p<0,05$. Rata-rata skor sikap sebelum pelatihan 79,17 menjadi 87,07 setelah pelatihan dan termasuk kategori baik, dengan peningkatan sebesar 10,7\%. Sedangkan pada kelompok kontrol tidak terdapat perbedaan $(\mathrm{p}>0,05)$ sikap antara pretes dan postes. Rata-rata skor sikap cenderung menetap $(79,03$ menjadi 80,47) dan termasuk kategori baik, dengan peningkatan sikap hanya $1,87 \%$.

Persentase peningkatan sikap antara kelompok perlakuan dan kelompok kontrol menunjukkan perbedaan bermakna $(p<0,05)$, sehingga dapat disimpulkan bahwa pelatihan berpengaruh terhadap peningkatan sikap safe injection bidan desa dalam pelaksanaan imunisasi.

Pengetahuan akan menentukan sikap. Pengetahuan yang baik belum tentu diikuti 
dengan sikap mendukung dan sebaliknya. ${ }^{15}$ Pada kelompok perlakuan, pengetahuan yang baik diikuti dengan sikap yang baik. Berbeda dengan kelompok kontrol, walaupun pengetahuan kurang baik namun memiliki sikap yang baik. Hal ini terjadi kemungkinan karena meningkatnya dampak imunisasi (KIPI) sehingga responden pada kedua kelompok cenderung memiliki sikap yang baik dalam pelaksanaan imunisasi.

Pelatihan akan memengaruhi pengetahuan dan pengetahuan memegang peranan penting dalam penentuan sikap dan perilaku. ${ }^{15}$ Hasil penelitian ini selaras dengan penelitian Dewi ${ }^{13}$ yang menunjukkan bahwa pelatihan mempunyai pengaruh terhadap peningkatan sikap pengelolaan program imunisasi. Hasil yang sama diperoleh dari penelitian Muflihah $^{14}$ yang memberikan informasi bahwa peningkatan sikap setelah pelatihan pada kelompok intervensi lebih tinggi daripada kelompok kontrol. Hasil penelitian ini selaras dengan penelitian yang dilakukan oleh Mboe dkk. ${ }^{17}$ yang menyatakan bahwa pengetahuan yang lebih baik dan sikap yang lebih positif ditunjukkan oleh petugas yang pernah mengikuti pelatihan dan supervisi. Hasil penelitian ini sesuai dengan pendapat Azwar ${ }^{18}$ yang menyatakan bahwa pembentukan sikap terutama karena pelatihan, disamping adanya pengalaman pribadi, budaya, media, dan emosional seseorang. Pelatihan yang diberikan kepada bidan menimbulkan kepercayaan atau keyakinan pada diri peserta pelatihan. Keyakinan ini semakin kuat pada saat peserta pelatihan berlatih keterampilan dengan praktik pelayanan imunisasi. Pengalaman emosional ketika melakukan pelayanan imunisasi akan memberikan kesadaran pada peserta pelatihan untuk berkomitmen melaksanakan safe injection dalam pelayanan imunisasi.

Pengetahuan dapat membentuk sikap tertentu dalam diri seseorang yang akhirnya memengaruhi tindakan. ${ }^{15}$ Tindakan terwujud dalam bentuk keterampilan. Keterampilan dapat diartikan sebagai kecakapan (kemampuan) yang berhubungan dengan tugas yang dimiliki dan dipergunakan pada waktu yang tepat. ${ }^{8}$ Keterampilan merupakan bagian dari kompetensi yang dapat dilihat secara langsung. Bidan desa sebagai bidan pelaksana, dituntut untuk terampil dalam melaksanakan pelayanan imunisasi rutin, sesuai dengan kewenangannya. Keterampilan lebih sukar dimiliki daripada pengetahuan.
Penilaian keterampilan dengan pengamatan langung ketika bidan melakukan pelayanan imunisasi dan termasuk dalam tingkatan keempat (does). Dari ketiga keterampilan yang diamati, keterampilan safe injection imunisasi BCG yang paling memerlukan perhatian, karena dilihat dari cara penyuntikan yang paling sulit yaitu secara intrakutan. Berbeda dengan keterampilan safe injection imunisasi DPT-HB dan campak yang diberikan secara subkutan dan intramuskuler.

Berdasar tabel 1, menunjukkan bahwa keterampilan safe injection bidan desa antara pretes dengan postes pada kelompok perlakuan dan kontrol menunjukkan perbedaan bermakna $(\mathrm{p}<0,05)$. Peningkatan keterampilan safe injection imunisasi BCG, DPT-HB, dan campak pada kelompok perlakuan lebih tinggi dibandingkan kelompok kontrol (50,73\%; $46,10 \% ; \quad 53,87 \%$ dengan $9,67 \% ; \quad 9,60 \%$; $12,37 \%)$. Persentase peningkatan keterampilan antara kelompok perlakuan dan kelompok kontrol menunjukkan perbedaan bermakna $(p<0,05)$. Sehingga dapat disimpulkan bahwa pelatihan berpengaruh terhadap peningkatan keterampilan safe injection bidan desa dalam pelaksanaan imunisasi.

Pelatihan meningkatkan pengetahuan, dan pengetahuan memegang peranan penting dalam penentuan sikap dan perilaku. Pada kelompok perlakuan, pengetahuan yang baik, didukung dengan sikap yang baik, dan terwujud dalam tindakan yang terampil. Pada penelitian ini pembelajaran keterampilan pada kelompok perlakuan dilakukan melalui tiga tahap, yaitu keterampilan awal (skill acquisition), peserta pelatihan melihat pelatih melakukan suatu keterampilan dan memperoleh memori visual dari prosedur yang dilakukan. Peserta pelatihan berlatih sampai mencapai pada tingkatan mampu dan percaya diri melakukan suatu prosedur (skill competency). Pada tingkat akhir, peserta pelatihan mahir (skill proficiency) setelah melakukan prosedur secara berulang-ulang. ${ }^{16}$ Semakin sering digunakan dan semakin sering dilatih, maka keterampilan seseorang akan semakin meningkat. ${ }^{19}$

Hasil penelitian ini selaras dengan penelitian Sasongko ${ }^{20}$ yang menyatakan bahwa terdapat perbedaan bermakna keterampilan petugas pengelola vaksin sebelum dan setelah mengikuti pelatihan. Penelitian serupa yang dilakukan Dewi ${ }^{13}$ menunjukkan bahwa pelatihan mempunyai pengaruh terhadap peningkatan 
keterampilan. Hasil yang sama diperoleh dari penelitian Muflihah ${ }^{14}$ yang memberikan informasi bahwa peningkatan keterampilan setelah pelatihan pada kelompok intervensi lebih tinggi daripada kelompok kontrol.

Hasil penelitian ini sesuai dengan penelitian Sulastri ${ }^{21}$ yang menyatakan bahwa keterampilan konseling bidan yang mengikuti pelatihan, kemungkinan 26 kali lebih terampil daripada bidan yang tidak mengikuti pelatihan. Penelitian serupa yang dilakukan Pracoyo ${ }^{22}$ menyatakan bahwa petugas yang belum mengikuti pelatihan memiliki risiko 7 kali lipat tidak benar dalam mengelola vaksin. Penelitian yang dilakukan Ameh et.al. ${ }^{23}$ di Somalia menunjukkan bahwa pelatihan berdampak positif pada kualitas pelayanan dan meningkatkan keterampilan.

Pada kelompok kontrol rentang keterampilan, baik keterampilan imunisasi BCG, DPTHB, maupun campak adalah 50-98, artinya tidak ada responden yang termasuk kategori terampil (nilai 100). Meskipun responden pada kelompok kontrol tidak ada yang termasuk kategori terampil, namun terjadi peningkatan rata-rata keterampilan antara pretes dan postes. Peningkatan keterampilan pada kelompok kontrol pada penelitian ini kemungkinan karena responden belajar dari kekurangan yang dilakukan pada saat pretes, sehingga mereka berusaha untuk memperbaikinya pada saat postes. Selain itu, waktu pengukuran keterampilan antara pretes dengan postes dalam kurun waktu satu bulan, memungkinkan responden untuk belajar memperbaiki keterampilan. Meskipun pelayanan imunisasi di posyandu hanya terjadwal tiap bulan sekali, namun pelayanan imunisasi di Puskesmas dibuka tiap minggu sekali. Hal ini memungkinkan responden kelompok kontrol, berusaha meningkatkan keterampilan dengan ikut serta ketika ada jadwal pelayanan imunisasi di Puskesmas. Hal ini sesuai dengan penelitian Patriani ${ }^{19}$ yang menyatakan bahwa keterampilan dengan semakin sering digunakan dan semakin sering dilatih, maka semakin meningkat keterampilan seseorang.

Meskipun pelayanan imunisasi merupakan tugas rutin, dalam penelitian ini keterampilan bidan dalam pelaksanaan imunisasi masih kurang sesuai dengan SOP (standar operational prosedur). Langkah-langkah dalam daftar tilik keterampilan yang tidak dilakukan oleh responden dari hasil pengamatan adalah konseling (skrening) pada awal dan akhir pelayanan, keterampilan dalam menyiapkan vaksin dengan benar (memeriksa label, kadaluwarsa, VVM, dan menyesuaikan suhu vaksin), keterampilan mengatur posisi dan fiksasi bayi dengan tepat, serta keterampilan dalam pengelolaan limbah imunisasi.

Dengan memerhatikan hal tersebut, maka skrening (wawancara, konseling) awal sebelum pelayanan imunisasi semestinya dilakukan dengan cermat. Skrening awal merupakan bagian penting dari keterampilan yang harus dilakukan oleh bidan sebelum memastikan bahwa imunisasi dapat diberikan. Selain itu perlu juga memperhatikan pengelolaan vaksin dan rantai vaksin. Bila pengelolaan vaksin dan rantai vaksin tidak baik, maka vaksin tidak akan mampu merangsang kekebalan tubuh secara optimal dan dapat menimbulkan KIPI yang tidak diharapkan. ${ }^{4}$

Peningkatan pengetahuan, sikap, dan keterampilan pada kelompok perlakuan merupakan tolok ukur dari keberhasilan pelatihan, yang pada akhirnya akan meningkatkan kompetensi bidan dalam pelaksanaan imunisasi dan dapat menurunkan KIPI. Hasil penelitian ini sesuai dengan penelitian yang dilakukan Dewi ${ }^{13}$ yang menunjukkan bahwa pelatihan mempunyai pengaruh terhadap peningkatan pengetahuan, perubahan sikap, dan peningkatan keterampilan.

Keterbatasan dalam penelitian antara lain adalah: 1.) Dalam kurun waktu penelitian, peneliti tidak bisa mengontrol kemungkinan interaksi yang terjadi antara responden kelompok perlakuan dengan kelompok kontrol, serta antara koordinator imunisasi dengan responden, terutama dalam hal keterampilan; 2.) Waktu melakukan pengamatan keterampilan pada masing-masing responden tidak sama, menyesuaikan dengan jadwal pelayanan di posyandu, sehingga memungkinkan responden untuk mempersiapkan diri dengan belajar; 3.) Pengamatan keterampilan dilakukan sendiri oleh peneliti sehingga dimungkinkan adanya subjektivitas dalam penilaian. Pelatihan berpengaruh terhadap peningkatan pengetahuan, sikap, dan keterampilan safe injection bidan desa dalam pelaksanaan imunisasi. Penelitian ini memberi informasi bahwa pelatihan diperlukan dan penting untuk dilaksanakan dalam upaya meningkatkan pengetahuan, sikap, dan keterampilan yang pada akhirnya akan meningkatkan kompetensi safe injection pelaksanaan imunisasi, khususnya bagi bidan di kabupaten Magetan. 


\section{Ucapan Terima Kasih}

Penulis mengucapkan terimakasih yang sebesar-besarnya kepada seluruh responden dalam penelitian ini. Ucapan terimakasih juga penulis sampaikan kepada pimpinan, staf P2P, tim pelatih dan fasilitator Dinas Kesehatan Kabupaten Magetan, serta koordinator imunisasi puskesmas yang telah banyak membantu dalam penelitian ini.

\section{Simpulan}

Simpulan penelitian ini adalah terdapat pengaruh pelatihan safe injection terhadap peningkatan pengetahuan, sikap, dan keterampilan bidan desa dalam pelaksanaan imunisasi. Peningkatan pengetahuan, sikap, dan keterampilan melalui pelatihan perlu dilakukan serta dilanjutkan dengan evaluasi dan supervisi suportif.

\section{Daftar Pustaka}

1. Kemenkes RI. Peraturan Menteri Kesehatan Republik Indonesia Nomor 42 tahun 2013 tentang penyelenggaraan imunisasi. Jakarta: Kemenkes RI; 2013.

2. Soetjiningsih, Ranuh IGNG. Tumbuh kembang anak. Jakarta: EGC; 1995.

3. Dinkes Kabupaten Magetan. Profil kesehatan kabupaten Magetan tahun 2012. Magetan; 2013.

4. Ranuh IG, Suyitno H, Hadinegoro SR, Kartasasmita CB, Ismoedijanto, Soedjatmiko. Pedoman imunisasi di Indonesia. Jakarta: Badan Penerbit Ikatan Dokter Anak Indonesia; 2011.

5. PATH. Injection safety and waste management. Seatle Washington: PATH; 2013.

6. Musa OI. Injection safety practice among health workers in static immunisation centres in an urban community of Nigeria. Niger Postgrad Med J. 2005;12(3):162-7.

7. Kemenkes RI. Peraturan Menteri Kesehatan RI Nomor.1464/Menkes/Per/X/2010 tentang ijin dan penyelenggaraan praktik bidan. Jakarta: Kemenkes RI; 2010.

8. Moeheriono. Pengukuran kinerja berbasis kompetensi. Bogor: Ghalia Indonesia; 2010.

9. Kemenkes RI. Keputusan Menteri Kesehatan RI Nomor.369/Menkes/SK/VII/2007 tentang standar profesi bidan. In: Kemenkes RI, editor. Jakarta: Kemenkes RI; 2007.

10. Nikula A. Vaccination competence the concept and evaluation. Finland: Department of Nursing Science University of Turku Finland 2011.
11. Wibawati TA, Soeharto, Supriyadi E, Ismara I. Efektivitas pembelajaran orang dewasa pada mata diklat kemitraan usaha di balai pemberdayaan masyarakat desa Yogyakarta. Yogyakarta: Universitas Negeri Yogyakarta; 2012.

12. Suciati, Irawan P. Pekerti. Buku 1.03: Teori belajar dan motivasi. Jakarta: PAU-PPAI Direktorat Jenderal Pendidikan Tinggi Departemen Pendidikan Nasional; 2005.

13. Dewi RS. Pengaruh pelatihan terhadap pengetahuan, sikap, dan keterampilan petugas dalam pengelolaan vaksin program imunisasi di unit pelayanan kesehatan kabupaten Karanganyar. Surakarta: Universitas Sebelas Maret; 2009.

14. Muflihah S. Pengaruh pelatihan deteksi dini tumbuh kembang anak terhadap pengetahuan dan keterampilan ibu dalam menstimulasi tumbuh kembang balita di Kabupaten Banjarnegara. Bandung: Universitas Padjadjaran; 2013.

15. Notoatmodjo S. Promosi kesehatan teori dan aplikasi. Jakarta: Rineka Cipta.; 2010.

16. JNPK-KR. Buku acuan. Pelatihan keterampilan melatih. Jakarta: JNPK-KR/POGI dan JHPIEGO; 2003.

17. Mboe M, Rahayuningsih SE, Rusmil K. Pengetahuan dan sikap bidan dalam praktik penyimpanan vaksin pada bidan praktik swasta. J Indon Med Assoc. 2012;62(10):402-6.

18. Azwar S. Sikap manusia teori dan pengukurannya. Yogyakarta: Pustaka Pelajar; 2009.

19. Patriani AA, Paramastri I, Priyanto MA. Pemberdayaan keluarga dalam rehabilitasi medik paru pada penderita penyakit paru obstruksi kronik di balai pengobatan paru-paru Yogyakarta. Berita Kedokteran Masyarakat. 2010;26(2):55-62.

20. Sasongko PW, Hadiwidjaja S, Suryani N. Perbedaan sikap dan keterampilan petugas pengelola vaksin program imunisasi pada unit pelayanan kesehatan di kabupaten Cirebon akibat diklat yang diberikan oleh dinas kesehatan. Surakarta: Universitas Sebelas Maret; 2011.

21. Sulastri, Wujoso H, Suryani N. Pengaruh pelatihan CTU dan pengalaman kerja bidan terhadap keterampilan konseling di puskesmas Balongpanggang Gresik. Surakarta: Universitas Sebelas Maret; 2013.

22. Pracoyo NE, Jekti RP, Puspandari N, W. DB. Hubungan antara pengetahuan dan sikap pengelola vaksin dengan skor pengelolaan vaksin di daerah kasus difteri di Jawa Timur. Media Litbang Kesehatan. 2013;23(3):102-9.

23. Ameh C, Adegoge A, Hofman J, Ismail FM, Ahmed FM, Broek Nvd. The impact of emergency obstetric care training in Somaliland, Somalia. International Journal of Gynecology and Obstetric. 2012;117:283-87. 